\title{
Types of speech acts and principles of mother's politeness in mother and child conversation
}

\section{Silpia Rahayu*}

Pendidikan Bahasa Inggris, Fakultas Pendidikan Bahasa, IKIP Siliwangi Cimahi, Indonesia

silviarahayu41@yahoo.com

*Corresponding author: silviarahayu41@yahoo.com

\begin{tabular}{|c|c|c|}
\hline & Revision: April 2, 2020 & \\
\hline \multicolumn{3}{|c|}{ ABSTRACT } \\
\hline \multicolumn{3}{|c|}{$\begin{array}{l}\text { In this study, the types of speech acts and the principles used by a mother nat } \\
\text { is investigated. The purpose of this study is to find the types and functions } \\
\text { communication with her child, and determine the function of the speech ac } \\
\text { method. The data were collected with Uninvolved Conversation Observatio } \\
\text { obtained from the speech were in Sundanese. To analyze the data, this study } \\
\text { to the theoretical foundation. The data analysis was performed using pragmat } \\
\text { on the pragmatic point of view. This analysis was employed to show the inter } \\
\text { explicitly or implicitly in her speech. The findings find that the dominant } \\
\text { conversation is assertive and the main principle is favor principle. The findin } \\
\text { main influencer in any child development. }\end{array}$} \\
\hline \multirow{2}{*}{\multicolumn{3}{|c|}{ Mother and child communication, Pragmatics, Speech acts }} \\
\hline & & \\
\hline \multicolumn{3}{|c|}{$\begin{array}{l}\text { Di dalam penelitian ini, dikaji jenis tindak tutur seorang ibu yang bernama } \\
\text { bernama Nio, serta prinsip yang terkandung di dalamnya. Tujuan penelitian } \\
\text { tindak tutur seorang ibu pada saat berkomunikasi dengan anak, serta men } \\
\text { penelitian yang digunakan adalah metode deskriptif kualitatif. Teknik peng } \\
\text { bebas; libat; cakap (SBLC), perekaman dan pencatatan. Data diperoleh dari t } \\
\text { percakapan berbahasa Sunda. Teknik analisis data menggunakan analisis deng } \\
\text { landasan teori. Analisis data dilakukan dengan menggunakan analisis data pr } \\
\text { sudut pandang pragmatik. Analisis ini digunakan untuk mengungkapkan ma } \\
\text { ataupun tersirat dalam tuturannya. Temuan pada penelitian ini adalah bahv } \\
\text { oleh ibu kepada anaknya dalam percakapan adalah asertif, sementara prinsip } \\
\text { ini sesuai dengan peran ibu sebagai pihak yang memengaruhi perkembangan }\end{array}$} \\
\hline & & $\begin{array}{l}\text { Rahayu } \\
\text { license }\end{array}$ \\
\hline & \multicolumn{2}{|l|}{ Komunikasi ibu dan anak, Pragmatik, Tindak tutur } \\
\hline & \multicolumn{2}{|c|}{$\begin{array}{l}\text { Rahayu, S. (2020). Types of speech acts and principles of mother's politeness in mother and child } \\
\text { conversation. KEMBARA: Jurnal Keilmuan Bahasa, Sastra, dan Pengajarannya, 6(I), I-9. doi: } \\
\text { https://doi.org/I0.22219/kembara.v6il.I1695 }\end{array}$} \\
\hline
\end{tabular}

\section{INTRODUCTION}

Linguistics is a study about language, how it functions when being put together and make a meaning as people use it to communicate with each other. Language is a tool for human communication, how people arrange the word and make a meaning to understand what people are saying. Febtrina (2019) stated that one focus not only on the structural aspect of a language but also how the language is used in the communication context. It means that language is automatically produced by human to communicate with other people.

Using language in communication is part of pragmatics study. Pragmatics is the language use of the speakers' meaning and the listeners' interpretation according to the contextual meaning. Pragmatics 
also talks about the meaning of expressions. According to Siddiqui (2018) pragmatics not only deals with the meaning of a given sentence; but also, it goes necessarily with a relative to the hidden meaning of the utterance. In general, pragmatics is the study of meaning in its context as the aspect of social achievement and belief.

Politeness is to honor people as a polite communication (Mahmud, 2019). When people make conversation with each other they use language to build the communication, in communication people have to consider the politeness principle. Politeness principle is speakers' strategies to maintain awareness of the hearers and self-image. People show politeness in their conversations or interaction to take care the social interaction with each other by putting face and good language. Mansoor (2018) as cited in Leech (2016) stated that politeness principles propose that one has to 'maximize the expression of polite beliefs, minimize the expression of impolite beliefs'.

Face Threatening Acts (FTA) is an act to express the face to be polite in the conversation by performing the acts. Tanto (2018) stated that Face Threatening Act is the act to force the speakers' determination on the hearers, and then (possibly) threaten the face of the hearers. Besides, Brown, Levinson, and Levinson (1987) as cited in (Nuraeni \& Wibowo, 2018) stated that there are two kinds of FTA that may happen to the speakers, there is (I) affront the utterance of negative face and (2) straight damage utterance of positive face. In our daily conversation with other people, we always use FTA's to threaten our face and also our face saving act to show good face in self-image. Face Saving Act (FSA) mentions to conserve a good self-image (Angginie, 2019).

Language development is an important aspect in a child's development because language is a vital tool for human life. Language development in children cannot be separated from the role of children's parents. Parents must understand the stages of language development in children so that they can provide a good stimulus in accordance with the stages of the child's age. Language acquisition can even begin when the baby is still in the womb. For example, a mother can invite babies to communicate about positive things. The inner contact between mother and fetus can be created properly if the psychological condition of the mother is stable. Harmony that is intertwined through communication can affect the child's psyche.

A good communication between children and parents will make a better relationship. This communication pattern can be realized through verbal forms, for example in daily conversation. Clear communication patterns will affect the child's language development and personality. In this case, the speech acts of the mother to the child become very important. Several studies on the speech acts of parents to children have been done by (Hasibuan, 2005; Siregar, 2003). In his research, Siregar reviewed the principles relating to speech acts, acquisition of speech acts and politeness tactics. Siregar (2003) explained the use of speech acts through forms of speech acts of petitions, apologies, complaints, praises, answering praises, and giving thanks. Meanwhile, Hasibuan (2005) examines speech acts and politeness tactics in Mandailing language. He explained the pattern of speech acts based on Searle's Theory, namely representative, directive, commissive, expressive and declarative speech acts as well as types of direct and indirect speech acts with cultural studies.

This study tries to continue the study of the speech acts of parents to children, with different subject of study. This study examines speech acts carried out by mothers to children in Sundanese conversation. In this study, it analyzes speech acts contained in conversations conducted by the subject with the most important function in family relationships, namely mothers. The two main questions in this study are (I) what type of speech acts are found in mother to child speech? and (2) what are the principles of politeness contained in the mother's speech to the child?

Dossena (2012) states that from birth, a baby has a biological "setting" for communication; they will be responsive to events caused by people around them. A mother has a very important role in the development of children's language skills. Since a human is born, his immediate environment influences the development of language skills. The idea of the extent of parental influence on children's language development is also emphasized by Vaughan and Clancy (2013) through describing unique patterns of interaction in pragmatic patterns in the corpus of conversation between family members. 
More specifically, Kampf (2013) cites in Blum-Kulka (1997), who explains the stages of language development in immigrant children in the United States, that pragmatic acquisition in children is strongly influenced by patterns of interaction between mother and child. This interaction provides a basic pragmatic ability approach because Blum-Kulka also believes in the family's dominant influence on children's language performance. Then, the idea that the child is still in a stage of cognitive development that is not too high, so the logic ability still lacks. This provides a foundation that supports the proof of the idea that children tend to follow the way of speaking to those closest to them-parents.

Quoting to Searle (1975), Bosco, Angeleri, Colle, Sacco, and Bara (2013) explain that the idea of speech acts in pragmatics that include certain treatments or actions carried out through words, for example asking for something, rejecting, thanking, greeting, praising, apologizing and complaining. It is in line with the explanation of Terkourafi (20II) who cites Brown et al. (1987) that speech acts are the production of sentences to state that the intentions of the speaker are known to the listener. In connection with this study, the ideas put forward by Bosco become the relevant foundation for traditional communication patterns in a family because of various speech acts such as asking for something, rejecting, thanking, greeting, praising, apologizing and complaining are common themes in conversations between family members. In the context of mother and child communication, children who have not yet reached a high level of cognitive thinking often listen to their mother (Goodwin \& Cekaite, 20I3). Goodwin and Cekaite (2013) explain that the position of children who tend to be passive provides an entry point that involves parents and children; parents' speech acts become more dominant and important in supporting children's language acquisition.

Moving on from the idea of the dominance of parental speech acts, it is necessary to put forward a number of speech act theories relevant to this study. Certain types of speech acts will appear in sentences spoken in mother and child conversations. Abolfathiasl and Abdullah (2013) explain that, first, speech act theory put forward by Austin which explicitly states that speech acts are divided into three, namely locution, illocution and perlocution. While Searle (1975) has another opinion. According to him, in a communication there are assertive, directive, commissive, expressive and declarative speech acts. From the two ideas described by Abolfathiasl and Abdullah (2013), Searle's explanation provides a very detailed perspective on the types of speech acts that can arise in conversations between mother and child. For this reason, this study will rely on Searle's notion about the types of speech acts. (I) In the context of speech acts of the mother to her child, the principle of politeness certainly exists. The basis for the study of politeness principles is explained by Arifin and Agustina (2017) who cites the idea of the Principle of Mutual Consideration from Aziz (200I) as follows: Regarding your speech partner, use a language that you yourself would be happy to hear if that language was used by someone else to you, and vice versa. (2) Regarding your speech partner, do not use a language that you yourself would not like if the language was used by someone else to you (Aziz, 200I).

In addition to the two principles above, Aziz (200I) outlines the principle of mutual tolerance as follows: (I) the principle of woundedness and flattering power; That is, a language expression has the potential that it will be able to make someone feel hurt or flattered to be happy. Therefore, be careful when using it. (2) The principle of sharing; That is, our speech partners have feelings just like our own. Therefore, when speaking using language expressions, consider the feelings of the speech partner as we should consider our own feelings. (3) The principle of first impressions; That is, our speech partner's assessment of our language politeness is basically determined by the first impression he gets about our language behavior when he communicates with us for the first time. Therefore, show that we have good intentions to work together and communicate with him. (4) Principle of sustainability; That is, the sustainability of our relationship with the speech partner in the future; it is basically determined by the way we transact through communication at this time. Therefore, try it out so that we can build mutual trust.

This section is important to point out, in order to emphasize the position of this study compared to some studies related to mother and child conversations. Mills (20II) discussed that some recent studies 
related to conversations in the family generally examine patterns of politeness of children towards parents. It is interesting to note that the opposite, parental politeness of children, apparently rarely get attention. Mills then also explained that the discourse of conversation in the family has a variety of patterns, ranging from informal to formal. In summary, Mills (201I) notion of politeness is also explained by Zifana (2013) who stated that the politeness analysis approach is related to contextual analysis. In this case, contextually this study tries to make a politeness analysis shift that normally targets children to parents, in this context: mother. The approach of this study is also expected to be able to explain the communicative behavior which is motivated by cultural elements, especially Indonesia, through the use of PSTR from (Aziz, 200I).

In 1977 there was a similar study of speech acts between mother and child entitled the development of conversation between mother and babies, In this research the hypothesis that mothers operate on the basis of a conversational model in interacting with their babies helps to explain some of the striking aspects of mother-infant interaction and some otherwise puzzling aspects of the mothers' speech register as well. This hypothesis accounts for the fact that mothers talk to young babies at all, and explains why they talk to them most while in a face to-face position or sharing activities, and least while feeding. Furthermore, it accounts for the very high frequency of questions in speech to babies: questions, especially tag-questions and other post-completers like 'Hmm?', are devices for passing the turn to the partner, which is precisely what the mothers are trying hardest to do. Another adjacency-pair used by mothers in much the same way is greetings; an analysis is currently under way of the situations in which mothers greet their infants, but preliminary observations confirm that mothers greet infants after only very short absences or separations, situations in which greeting an adult would be quite abnormal. Both questions and greetings enable the mother operating within the conversational mode to treat any response on the part of her child as a communicative response, because the mothers' conversational rules dictate that the unit-types which follow questions or greetings be responses. Very often, of course, the question or greeting was not followed by any behavior which could be interpreted as communicative, and then the mother was forced into conversational repair procedures such as repetition or taking the baby's turn. The way mothers talk to their babies is one reflection of their belief that the babies are capable of reciprocal communication. their choice of the conversational mode not only reflects this belief, but also provides opportunities fur reinforcing.

\section{METHOD}

Denzin and Lincoln offer a useful insight into the complexity of the approach: "Qualitative research is difficult to define clearly. It has no theory and paradigm that is distinctively its own...nor does qualitative research have a distinct set of methods or practices that are entirely its own (Denzin \& Lincoln, 1994). As the statement above shows, qualitative research encompasses variety of methods in a variety of subject areas. In this respect qualitative research might be regarded as an overarching research approach that embraces a wide range of methods which are focused on examining the meaning that underpins the issues under investigation. Qualitative method is able to allow researcher to be flexible for conducting specific research, aids the sensitive examination or difficult topic if a trust relationship is developed between research and researcher, and allows researcher to create links between different aspects of people's lives; such as the employment, leisure time and domestic sphere (Creswell, 20I4).

In this study, the principle of mutual tolerance from Aziz (200I) was used to support the analysis of politeness patterns or the principle of speech from mother to her child with the consideration that the PSTR was suitable for the context of conversation in Indonesia. This study was a qualitative descriptive study. Descriptive qualitative research is measured proper in order to find information related to the employment of technique, media, method, and process (Apsari, Lisdawati, \& Mulyani, 2019). Descriptive method was chosen because the research carried out the aims to clearly describe the object under study naturally and was suitable for developing theories built through the data (Mills, 20II). The data needed in this research was in the form of speech from the conversation of a mother and her child 
who was only four years old. In this study, the researcher examined a mother, who worked as a housewife, when she interacts with her child-a 4 year-old-boy. This research was conducted November 2019 by taking data for one month. The conversation was in Sundanese. In this study, conversations were recorded and focused only on the mother's utterances. The mother's speech was then sorted according to the type of directive, commissive, expressive, assertive and declaration. The situation when the conversation was spoken was when the mother and child carried out their daily activities and when they discussed personal issues. The conversation was recorded using a Sony TCM I50 recorder. In addition, the recording was carried out to complete the speech data. Then the data were analyzed and categorized into assertive, directive, commissive, expressive or declaration speech acts.

The data analysis was performed using pragmatic data analysis namely language analysis based on the pragmatic point of view. The method used in this study was the identification method, which is a method for determining speech acts based on their characteristics. The followings are the stages of the data analysis: (I) identifying speech to determine the type of speech acts and politeness principles, (2) grouping data into tables based on the type of speech acts and politeness principles, (3) presenting the data in order to obtain results to see the distribution of speech acts and politeness principles.

\section{FINDING AND DISCUSSION \\ Types of Speech Acts of Mothers}

The findings show that the dominant type of speech act used by mothers is assertive/representative speech act whose function is to state and explain. It is then followed by directive speech act used to instruct and expressive speech act to praise. The full findings are presented in Table I below.

Table I

Findings on the Types of Mother's Speech Acts

\begin{tabular}{llcc}
\hline No. & \multicolumn{1}{c}{ Types of Speech Act } & Total & $\%$ \\
\hline I. & Assertive/representative & 24 & 46,15 \\
2. & Directive & $\mathrm{I} 2$ & 23,08 \\
3. & Expressive & 8 & 15,38 \\
4. & Commissive & 5 & 9,62 \\
5. & Declarative & 3 & 5,77 \\
& & 53 & Total \\
\hline
\end{tabular}

The dominant tendency of assertive type with the function of stating and explaining can be understood based on the role of mothers who provide a lot of information intake to children. Here are a few examples.

(I) Bubuahanah téh asalna tina kekembangan. [Fruits come from flowers.]

(2) Upami seeur emam wortel, éngké socana sae. [If you eat a lot of carrots, your eyes will be healthy]

Turning to the relatively many types of directives with the command function, this can also be understood given the cognitive condition of a four-year-old child who still does not have a good initiative.

(3) Tamas heula geura jug! [Wash your face first!]

(4) Emam heula! [Eat first!]

In the expressive type, a strong function is praise. In the context of the relationship between mother and child, it is also part of the mother's role to provide rewards for the child's achievement and can be understood as a way for the mother to raise the child's spirit.

(5) Ade mah pinter: [you are smart]

(6) Enggal da bageur. [hurry up, you are a good kid] 
The type of commissive, which only revolves around the function of offering, shows that the mother carries out her role as a parent who needs to provide an adequate support for her child.

(7) Emam nya? [Eat, huh?]

(8) Hoyong jajan, alim? [Do you want snacks?]

The same role also appears in declarative speech types whose function only prohibition. In this type of speech, the mother also has a role in determining what the child may or may not do.

(9) Teu kenging jajan nu di sisi jalan. [don't buy any street food]

(I0) Amengna tong tebih-tebih. [don't play too far]

In the relationship of mother and child, the two speakers who involve in the conversation are also involved in psychological communication, in addition to the functions performed by several types of speech acts. Therefore, the mother and child, as speakers, open up to each other in conversation. This is shown by the dominant use of assertive speech acts that have the intention to express and convey something.

The other side of the communication relationship established by the mother is her activeness in providing direction that is characterized by the dominant use of directive speech act with the ordering function. In this case, the mother tells the child to do something because indeed the child, as opposed to speech, is still a child who tends to still have more dependence on his mother. Meanwhile, commissive and declarative speech acts can be interpreted as a mother's instinct to look after and care for her children.

In this research, the use of assertive speech acts is dominated by the intention to express and convey something. The dominant tendency of assertive type with the function of stating and explaining can be understood based on the role of mothers who provide a lot of information intake in the form of explaining or explaining information to children as compared to other speech acts.

\section{The Principles of Politeness}

The findings show that out of the fifty-three utterances made by the mother, there is not any significant violation of the principle of mutual tolerance. However, some violations are related to the principle of sharing. In this study, the principle of first impressions is not taken into account, bearing in mind that the mother and child live under one roof and interact every day, so that the communication has been established for a long time. Likewise, the principle of sustainability, given the age of the child as opposed to the speech is still in the cognitive stage that has a high dependence on the mother. The following Table 2 summarizes the findings.

Table 2

Conformity of Speech with the Principle of Mutual Tolerance

\begin{tabular}{llcc}
\hline No. & \multicolumn{1}{c}{ Suitability } & Total of utterances & $\%$ \\
\hline I. & Suitable with four principle & 42 & 79,25 \\
2. & violates the principle of wounded and flattering; & 8 & 15,09 \\
3. & violates the principle of sharing; & 3 & 5,66 \\
4. & violates the principle of first impression; & 0 & 0 \\
5. & violates the principle of sustainability; & 0 & 0 \\
& Total & 53 & I00 \\
\hline
\end{tabular}

From the table above, it can be seen that the mother's speech is generally very polite because it is in accordance with the four principles in the Principle of Mutual Tolerance. However, there are significant figures for violations of one of the principles, namely the principle of woundedness and flattering power. The following examples (II) and (I2) show the violation of this principle. 
(II) Ih atuh naha Ade bet bodo? [Why are you so stupid?]

(I2) Baong ah ade mah! [you are naughty!]

The two examples above are considered to violate the principle of injury and flattering power because the two forms of speech have the potential to hurt the child. Especially, when considering the child who is still at the cognitive stage with a strong dependency on the mother.

Furthermore, violations of the principle of sharing are also indicated. The following are examples.

(13) Emam sadayana tong dipilihan emamna! [eat all your foods, don't be picky.]

(I4) Tos gera pareuman tipina! [Turn off the television!]

For the record, example (I3) is said when the child was eating vegetable soup; he only ate rice with the side dish, leaving the vegetable uneaten. Example (I3) is considered to violate the principle of sharing the taste because in this case the mother does not feel what the child prefers to eat. In other words, the mother actually has other alternatives to encourage the child to eat vegetables without declarative speech acts, whose function is to directly prohibit the child in choosing food.

Meanwhile, example (I4) is said in a situation where the child was eating while watching TV. This speech also violates the principle of sharing feelings because it is almost in line with the example (I3), the mother has another alternative to encourage the child to turn off the television without showing low empathy for what seems to be the child's favorite.

Several studies on the speech acts of parents to children have been done by (Hasibuan, 2005; Siregar, 2003). In his research, Siregar reviewed the principles related to speech acts, acquisition of speech acts and politeness tactics. Siregar (2003) explained the use of speech acts through forms of speech acts of petition, apologies, complaints, praise, answering praise and giving thanks. Meanwhile, Hasibuan (2005) examines speech acts and politeness tactics in Mandailing language. He explained the pattern of speech acts based on Searle's Theory, namely representative, directive, commissive, expressive and declarative speech acts as well as types of direct and indirect speech acts with cultural studies.

Mother's utterances are dominated by the types of commissive speech acts offered and declarative prohibits. This is in accordance with the role of the mother as the party that gives influence to the development of her child in various ways.

The position of this study is important to put forward, in order to emphasize the position of this study as compared to some studies related to mother and child conversations that have been there before. Mills (20II) explained that some recent studies on conversations in the family generally examine patterns of politeness of children towards parents. It is interesting to note that the opposite, parental politeness of children, apparently rarely catch the attention. Mills then also explained that the discourse of conversation in the family has a variety of patterns, ranging from informal to formal. In summary, Mills (20II) notion of politeness is also explained by Zifana (2013) who stated that the politeness analysis approach is related to the contextual analysis. In this case, this study tries to make a politeness analysis shift that normally targets children to parents, in this context: Mother. The approach of this study is also expected to be able to explain the communicative behavior which is motivated by cultural elements, especially Indonesia, through the use of PSTR from Aziz (200I) which is considered in accordance with the context of the discourse of conversation in Indonesia.

Based on the theory of Aziz (200I) which stated that in communication there are assertive, directive, commissive, expressive and declarative speech acts, the findings prove that there are suitability of conversations between mothers and children which can be categorized into these types of speech acts, with the assertive speech acts as the dominant speech act.

The implication of this finding for parenting, especially the development of child communication, is that the way the mother communicates with the child can influence the child's pattern of language development. Explaining something to the child using a language that the child understands can help the child to easily capture what the mother explains or commands. It would be different if the 
mother does not use the speech act theory as Aziz (200I) when communicating with the child; there may be many misunderstandings between mother and child that can lead to child's confusion over what the mother says.

\section{CONCLUSION}

From the results of the research, it can be concluded that the types of speech acts that occur in mother to child speech are assertive, directive, commissive, expressive and declaration speech acts. The mother's utterances are dominated by the types of commissive speech acts offered and declarative prohibition. It is in accordance with the role of the mother who gives influence to the development of her child in various ways. The politeness of the mother in her speech acts seems very dominant and generally fulfills all the principles in the Principle of mutual tolerance. However, there is a significant number of violations of the principle of wounded and flattering as well as the principle of mutual sharing. It is something that needs more attention as the child can be very exposed to this violation of politeness.

\section{ACKNOWLEDGEMENTS}

The researcher would like to extend their deepest gratitude to the Head of English Education Study Program IKIP Siliwangi Cimahi who always motivates all lecturers to always carry out research, and my husband who always supports me during the completion of this research.

\section{REFERENCES}

Abolfathiasl, H., \& Abdullah, A. N. (2013). Pragmatic strategies and linguistic structures in making 'suggestions': Towards comprehensive taxonomies. International Journal of Applied Linguistics and English Literature, 2(6), 236-24I. doi: http://dx.doi.org/I0.7575/aiac.ijalel.v.2n.6p.236

Angginie, V. A. (2019). Analysis about politeness in "Barbie as a princess and pauper movie". Professional Journal of English Education, 2(3), 3I0-3I8. doi: http://dx.doi.org/I0.22460/project.v2i3.p3I0-3I8

Apsari, Lisdawati, I., \& Mulyani, E. R. (2019). The implementation of project based learning in coursebook evaluation classroom. Jurnal Ilmiah P2M STKIP Siliwangi, 6(2), 187-195. doi: https://doi.org/I0.22460/p2m.v6i2p\%25p.I446

Arifin, J., \& Agustina, L. (2017). Bentuk tindak tutur persuasi perawat dan pasien di Puskesmas Banua Lawas Kabupaten Tabalong. Stilistika, 2(2), 250-26I. doi: https://doi.org/I0.33654/sti.v2i2.402

Aziz, E. A. (200I). Aspek-aspek budaya yang terlupakan dalam praktek pengajaran bahasa asing. Paper presented at the KIPBIPA IV, Denpasar.

Bosco, F. M., Angeleri, R., Colle, L., Sacco, K., \& Bara, B. G. (20I3). Communicative abilities in children: An assessment through different phenomena and expressive means. Journal of child language, 40(4), 74I-778. doi: https://doi.org/I0.I0I7/S03050009I300008I

Brown, P., Levinson, S. C., \& Levinson, S. C. (1987). Politeness: Some universals in language sage. Cambridge: Cambridge University Press.

Creswell, J. W. (20I4). Research design: Qualitative, quantitative and mixed methods approaches. Thousand Oaks, CA: Sage Publications Inc.

Denzin, N. K., \& Lincoln, Y. S. (1994). Handbook of qualitative research. Thousand Oaks, CA: Sage.

Dossena, M. (2012). I write you these few lines: Metacommunication and pragmatics in nineteenthcentury Scottish emigrants' letters. In U. d. Hübler (Ed.), Investigations into the metacommunicative lexicon of english: A contribution to historical pragmatics. Amsterdam dan Philadelphia: John Benjamins Publishing Co.

Febtrina, R. (2019). A pragmatics analysis of politeness strategies and cooperation principles in beauty and the beast movie. IOSR Journal of Research \& Method in Education (IOSR-JRME), 9(3), 
6-II.

Retrieved from

https://pdfs.semanticscholar.org/96dd/7f84Ifd894e2b763I543dfIf9b3aIb66e929.pdf

Goodwin, M. H., \& Cekaite, A. (2013). Calibration in directive/response sequences in family interaction. Journal of Pragmatics, 46(I), I22-I38. doi: https://doi.org/I0.1016/j.pragma.2012.07.008

Hasibuan, N. H. (2005). Perangkat tindak tutur dan. siasat kesantunan berbahasa (data bahasa Mandailing). Jurnal Ilmiah Fakultas. Bahasa dan Seni Universitas Sumatera Utama, 5(2), 45-53. Retrieved from http://repository.usu.ac.id/bitstream/handle/I23456789/2I254/logokt2005-I\%20\%283\%29.pdf? sequence $=\mathrm{I}$ \&isAllowed $=\mathrm{y}$

Kampf, Z. (2013). Blum-kulka, shoshana. In C. A. Chapelle (Ed.), The encyclopedia of applied linguistics. Blackwell: Blackwell Publishing Ltd.

Leech, G. N. (2016). Principles of pragmatics. New York: Longman.

Mahmud, M. (2019). The use of politeness strategies in the classroom context by English university students. Indonesian Journal of Applied Linguistics, 8(3), 597-606. doi: https://doi.org/I0.17509/ijal.v8i3.I5258

Mansoor, I. K. (2018). Politeness: Linguistic study. International Journal of Research in Social Sciences and Humanities, $8(4), \quad$ I67-I79. Retrieved from http://www.ijrssh.com/images/short_pdf/I53868I625_II_Iman_Kareem_Mansoor.pdf

Mills, S. (20II). Discursive approaches to politeness and impoliteness. In L. P. R. Group (Ed.), Discursive approaches to politeness. Berlin dan Boston: Walter de Gruyter GmbH \& Co. KG.

Nuraeni, W., \& Wibowo, N. A. (2018). Analyzing face threatening act in whatsapp group. PROJECT (Professional Journal of English Education), I(4), 366-373. doi: http://dx.doi.org/I0.22460/project.vIi4.p366-373

Siddiqui, A. (2018). The principle features of English pragmatics in applied linguistics. Advances in Language and Literary Studies, $9(2), \quad 77-80 . \quad$ doi: http:/ / dx.doi.org/I0.7575/aiac.alls.v.9n.2p.77

Siregar, H. U. (2003). Pemerolehan tindak tutur yang berhubungan dengan kesantunan: Kasus pemerolehan bahasa Jepang sebagai bahasa asing di Indonesia. In Soekamto (Ed.), Cakrawala Baru. Jakarta: Yayasan Obor Indonesia.

Tanto, T. (2018). Request strategies in Indonesian: An analysis of politeness phenomena in text messages. Journal of Language and Literature, I8(2), I37-I45. doi: http:/ / dx.doi.org/I0.2407 I/joll.vI8i2.I569

Terkourafi, M. (20II). Why direct speech is not a natural default: Rejoinder to Steven Pinker's "Indirect speech, politeness, deniability, and relationship negotiation”. Journal of Pragmatics, 43(II), 2869-287I. doi: http:/ /dx.doi.org/I0.I0I6/j.pragma.201 I.05.006

Vaughan, E., \& Clancy, B. (2013). Small Corpora and Pragmatics. In J. Romero-Trillo (Ed.), Yearbook of Corpus Linguistics and Pragmatics 2013. Dordrecht, Heidelberg, New York, and London: Springer.

Zifana, M. (20I3). Resensi buku. Linguistik Indonesia, 3I(2), 207-208. 